\title{
Can Narrative Economics Justify Economic Fluctuations and Inequality? An Approach from Micro to Macro Perspective
}

\author{
Monika Gaur ${ }^{1}$, Ravi Kant ${ }^{2}$ \\ ${ }^{1}$ Faculty of Management Studies, University of Delhi, Delhi, India \\ ${ }^{2}$ Sri Ram College of Commerce, University of Delhi, Delhi, India \\ Email:mgaur177@gmail.com, ravinirvana87@gmail.com
}

How to cite this paper: Gaur, M., \& Kant, R. (2021). Can Narrative Economics Justify Economic Fluctuations and Inequality? An Approach from Micro to Macro Perspective. Theoretical Economics Letters, 11, 1-20. https://doi.org/10.4236/tel.2021.111001

Received: December 4, 2020

Accepted: January 4, 2021

Published: January 7, 2021

Copyright $\odot 2021$ by author(s) and Scientific Research Publishing Inc. This work is licensed under the Creative Commons Attribution International License (CC BY 4.0).

http://creativecommons.org/licenses/by/4.0/ (c) (i) Open Access

\begin{abstract}
The opus dwells on aspects of building narrative, especially for state policies. It thoroughly examines economic narratives as a reason for the economic fluctuations and aggrandizement of resources. The present work is a watershed development while explaining the factors behind the dynamics of the economic system, engages upon a bottom-up approach, and provides a model for the impact of narrative-driven choices at the micro and macro levels contemplating the role of narrative in escalating inequality. The present research is intrigued by the fact that narratives form an inextricable role while forming and implementing state policies; moreover, non-developmental narratives can dampen the impact of desired policy and economic objectives. Importantly, since facts do not always back narratives, erratic economic and social outcomes petered out from conventional policy action. A few wealthy and resourceful people can swing the narrative and build upon by the low literacy, learning poverty, lack of rational approach, religious and caste factors. Such narratives subsequently influence people's decisions, often their political decision, which enhances their probability of acquiring more wealth, leading to a perpetual concentration of wealth and power in few hands. The reason for the "perpetual concentration" of wealth and power lies with the existence of strong narratives that directly or indirectly reinforces aggrandizement and causes penury to the few left out underprivileged sections. Such inequality will be nothing short of being "narrative-driven inequality". The research also emphasized the role of institutions, media, and technology, which unanimously plays a crucial role in creating, validating, and disseminating narratives. An overall ethical responsibility must be felt and shared for the common good and shared prosperity. The participative decision making helps dilute non-developmental narratives.
\end{abstract}




\section{Keywords}

Narratives, Choices, Economic Policies, Growth, Fluctuation, and Inequality

\section{Backdrop}

Several factors influence the decision-making process of an individual. In decision-making and choice, individuals choose what they want, sometimes based on knowledge and sometimes under the influence of the set of values (Kaltsounis, 1987). Society is one of the key factors that establish an individual's system of values, and the decision-making process is a complex process in which society is involved (Allison, Jordan \& Yeatts, 1992). In both economic and behavioral literature, individuals sometimes make choices that are suboptimal from the economic perspective, and their rationality is constrained due to, amongst other things, limitations to their cognitive capacities (Simon, 1955; Beckar, 1974; Thaler, 2015). Besides, behavioral economics has already made an effort to integrate social factors in the economic models, for instance, by accounting for inequity aversion, reciprocity, fairness, or social reputation (Beckar, 1974; Fehr \& Schmidt, 1999; Bolton \& Ockenfels, 2000; Rabin, 1993; Benabou \& Tirole, 2006). The process of decision making is discussed as a process of making a rational choice; it is communicated that the process is influenced by numerous factors other than rational parameters (Can, 1991; Sağır, 2006). One of these factors effective in the emergence of people's decisions is social factors (Brown et al., 2011).

In the process of choice and decision, the existence of a popular narrative can influence the decisions of the individual and community. It generally prevails in society concerning how the economy performs and how people behave in it themselves play a dominant role in influencing behavior (Shiller, 2019). The narratives can be conceptualized as a fundamental instrument of discernments and expressions to establish the phenomena and influence the events through individuals' decisions. In the words of Abbott "Narrative is the representation of events, consisting of story and narrative discourse, story is an event or sequence of events (the action), and narrative discourse is those events as represented (Abbott, 2002). It is not easy to establish the direct association between narratives and major economic outcomes (Shiller, 2017). However, one can indirectly establish the relationship by analyzing the effect of narratives on individuals' choices and subsequent to collective decisions.

The motive of a narrative can be pro-developmental or non-developmental. The agent(s) or institution(s) create and disseminate the purposeful narratives for their motives. These motives can exist in terms of accumulation of resources, the polarization of power and reputation. The narratives can be more potent in influencing public opinion and decisions than logic, facts, and figures. The widespread reach and its impact on the individual(s) decisions are a significant 
indicator of the power of narratives. The populist promises based narratives with high proliferation and reachability are potent in influencing individual behavior through alteration in choices and hence decisions. The success and failure of the narratives can also depend on the quantitative variables like country's or community's literacy, i.e., the educational level, and the qualitative variables such as collective peoples' ideology, belief, faith, logic, and wisdom. Besides, the availability of economic resources, penetration of technology, mode of spreading narratives, the quantum of social and electronic media usage by the people, and intensity of attending speeches and rallies facilitates the building of a narrative and its subsequent sustainability.

The present study provides a comprehensive view of how narrative influences individuals' choices to economic policies and provides a crucial linchpin in wealth concentration. To the best of the authors' knowledge, the existing literature has not touched upon this nexus and remains new research. The study is segregated into two parts, first, micro perspectives that deal with how narratives can influence an individual's decisions and, subsequently, community decision. Secondly, it conceptualizes the implications of narratives to alter the decisions of the political unit of the country at the macro level. Further, it deliberate upon inequality and concentration of wealth. The study's flow is as follows: the existing section discusses the backdrop of the study, the subsequent section, i.e., section II, enumerates the review of literature, and section III enumerates the micro perspective on narratives and their effects. Section IV presents a macro view on narrative economics while deliberating on narrative and inequality, and section $\mathrm{V}$ iterates the study's epilogue.

\section{Review of Literature}

There are limited studies available in the context of "homo economicus", which explains how individuals at the micro and people at the macro level behave in real economic life. In contemporary thinking, behavioral economics gained much more attention to explain economic psychology and is widely being adopted in mainstream economics analysis (Simon, 1955; Kahneman, 2011; Thaler, 2015; Allen \& Hockey, 2008). To estimate and optimize welfare, people generally do not engage in a calculation, and they exercise respective forms of "bounded rationality." Individuals make economic decisions using the "rule of thumb" and "heuristic" conscionable to save time and effort. "Herd Behaviour" can be an excellent example of that kind of decision making by people. In "herd Behaviour," people follow others' example, as happens, for instance, in the stock market. Simultaneously, economic psychologists and sociologists have been empathetic upon the significance of social influences on forming economic tastes and preferences (McGregor \& Pouw, 2017). People do not perform exclusively in their self-interest alone; they have strong connections and moral views, which lead to various forms of co-operative, affectionate, and selfless behavior and compliance with social norms. That kind of behavior may not be subject to a 
calculated or individualistic logic at all. Instead, it suggests a "social" human being an essential economic agent (Shiller, 2019; Snower \& Akerlof, 2016). In this context, one can identify that economic action or decision is dependent on societal structures, institutions, and relationships. The exogenous economic system is less likely to drive peoples' tastes and preferences. They can be actively influenced by modes such as disseminating information (biased or unbiased) through advertisements, the effect of new technologies and social networks, and institutions. The narratives which commonly prevail in society regarding how the economy performs and people behave in it themselves play a dominant role in influencing behavior (Shiller, 2019). The mainstream economic structure of competitive markets and neoliberalism has always intended to rationalize what in the real world is a broad scope of various kinds of market arrangement. The nature of factors that are responsible for economic outcomes can be qualitative and quantitative. The narratives are not visible in the socio-economic policies but can potentially influence the major economic events.

Almost two decades ago, most of the macroeconomists failed to predict the event of 2007-2008, the Global Financial Crisis (GFC). The context of the GFC in 2007-2008 was remarkably different from the 1930s' Great Depression. The economic weakness of many developed economies despite the very low-interest rates has suggested thinking over the fundamental reappraisal of neo-classical based theories and models. The dominant focus has been made on the financial markets since most crises influenced economies due to the financial sector. The increasing trend of the financialization of many economies and their impact on various macro-economic indicators such as income, consumption, investments, unemployment, and inflation can be empirically visualized. As identified, higher dependency on financial markets is one reason behind the stagnant economic activities in many developed economies. Some economists have been and are being focused on the micro observations on the causes of the crash. These micro observations are dependent on peoples' economic behavior, specifically in the context of the financial market. For instance, speculative and short-term financial behavior plays a significant role in real estate investments and the rise in the "shadow banking" system (Kay, 2012; Lazonick, 2014; Nesvetailova, 2019).

The study of "narrative economics" is now considered a relevant field for identifying economic events. It is not easy to establish the importance of changing narratives in causing economic fluctuations (Shiller, 2017). Fortunately, there have been some studies along with real controlled experiments presenting people respond strongly to narratives in the field of health interventions (Slater et al., 2003), Philanthropy (Weber et al., 2006), journalism (Machill et al., 2007), marketing (Escalas, 2007); education (McQuiggan et al., 2008); and aggregate economy (Shiller, 1984; 2016; 2019; Akerlof \& Shiller, 2009; 2015). Some more studies are available on narratives and their impact on the social systems such as (Shiller, 1984), to a new "çulturnomics"; or "humanomics" (McCloskey, 2016); or for more narratives in economics (Morson \& Schapiro, 2017). 
One must also consider that stories tend to be strategic, fine-tuned by politicians, advertisers, or other interested parties (Akerlof \& Shiller, 2015). People with an aptitude for story-telling see great fortune in monkeying with stories to have them go viral. Falk \& Tirole (2016) call them "narrative entrepreneurs." Glaeser (2005) refers to the "supply of stories," exemplified by hate-creating stories crafted, produced, fashioned for political advantage. Gino et al. (2016) describe concoctors of excuses as "motivated Bayesians" meaning that these people start to believe the fake news that they generated for self-advantage.

\section{Micro Perspective on Narratives and Its Effects}

\subsection{Basic Assumptions}

Hicks \& Allen (1934) contemplated the fundamental indifference curve approach, which postulates the utility's ordinal nature, which can assuredly be ranked. The approach of consumer behavior and equilibrium relies upon the following assumptions:

1) Rationality: consumers are rational, i.e., they make the best choice, maximizing utility for a given price and income.

2) Complete information: the consumer has complete knowledge of relevant information.

3) Ordinal utility: consumers can rank their preferences using the indifference curve.

4) Diminishing Marginal Rate of Substitution: the marginal rate of substitution of $\mathrm{X}$ for $\mathrm{Y}$ diminishes as more and more of good $\mathrm{X}$ is substituted for good $\mathrm{Y}$, i.e., as the consumer has more of good $\mathrm{X}$, he is willing to forego less of good $\mathrm{Y}$.

5) Consistency and transitivity of choices: if the consumer chooses good A (or bundle) over $\mathrm{B}$ in one time period, he will be consistent with his choices. $\mathrm{He}$ shall not choose $\mathrm{B}$ over $\mathrm{A}$ at another time if both the bundles are available. Also, if a consumer prefers good $\mathrm{A}$ (or bundle) over $\mathrm{B}$ and $\mathrm{B}$ over $\mathrm{C}$, then $\mathrm{A}$ is assumed to be preferred over $\mathrm{C}$ as well, i.e., $\mathrm{A}>\mathrm{B}, \mathrm{B}>\mathrm{C}$ then, $\mathrm{A}>\mathrm{C}$.

\subsection{Narratives and Instability of Indifference Curve}

There has been a wide array of research focussing on the limitations of the indifference curve hypothesis (Samuelson, 1947; Leibenstein, 1950; Mishan, 1961). The present study focuses on how narratives influence consumer choices and hence make the indifference curve unstable. It is crucial that the assumption of complete information makes people vulnerable to prevalent narratives in the economy and can guide and impact choice behaviors if they are related to the goods under consideration in any way. Existing literature testifies that people acknowledge the narratives and render a strong response to them (Slater et al., 2003; Weber et al., 2006; Escalas, 2007; Machill et al., 2007; McQuiggan et al., 2008). The study explores the impact of existing or newly formed narratives over consumer choices and hence decision. We use an example of portfolio investment where an investor chooses between shares and Bitcoins while reaching his 
optimal investment portfolio.

Given the indifference curve map (Figure 1). The consumer is on $\mathrm{IC}_{1}$, such that he is indifferent between bundle A, B, and C. Now, if the consumer has a narrative ${ }^{1}$ built over bundle A (say), i.e., bitcoins provide relatively higher return given the risk, such that he automatically prefers A over B and C. (Figure 1)

Now, the consumer is deriving a higher satisfaction from A than B or C. Importantly, he moves to a higher indifference curve, i.e., IC', but, since A lies on both the IC's, i.e., IC and IC', the indifference curves tend to cross each other, and hence it violates the assumption of consistency. Here, he is indifferent between $\mathrm{A}, \mathrm{B}$, and $\mathrm{C}$, between $\mathrm{A}^{\prime}, \mathrm{B}^{\prime}$ and $\mathrm{C}^{\prime}$, making his choices inconsistent.

The budget constraint and narrative choice.

Narratives guide the consumer's choice (existing or formed during his choice); he tries to spend his income in such a way that he consumes more of narrative-driven good and less of the other. At a micro level, individuals skew their consumption towards the choices guided by narratives (narratives that favor the consumption of specific goods), Bitcoins in our case.

Figure 2 illustrates that the consumer made a rational choice in the left panel, where the equilibrium is at point $\mathrm{E}$. However, if the narrative guides him, he chooses bundle $\mathrm{A}$, and the budget line pivots according, leaving him with more

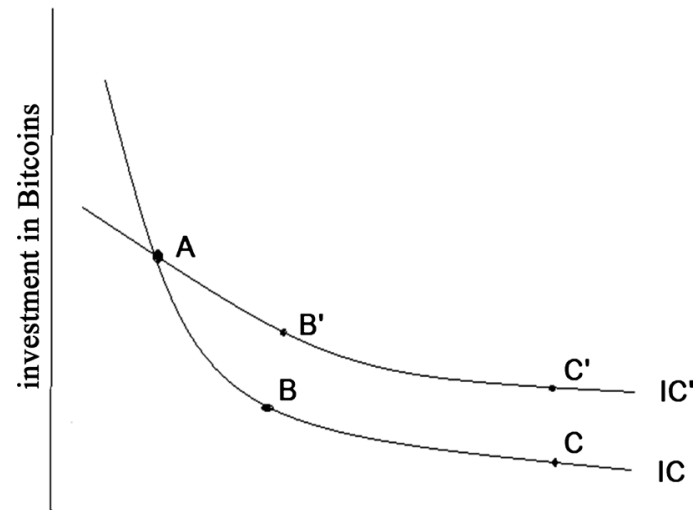

in vestment in shares

Figure 1. Narratives leading to the intersection of indifference curves.

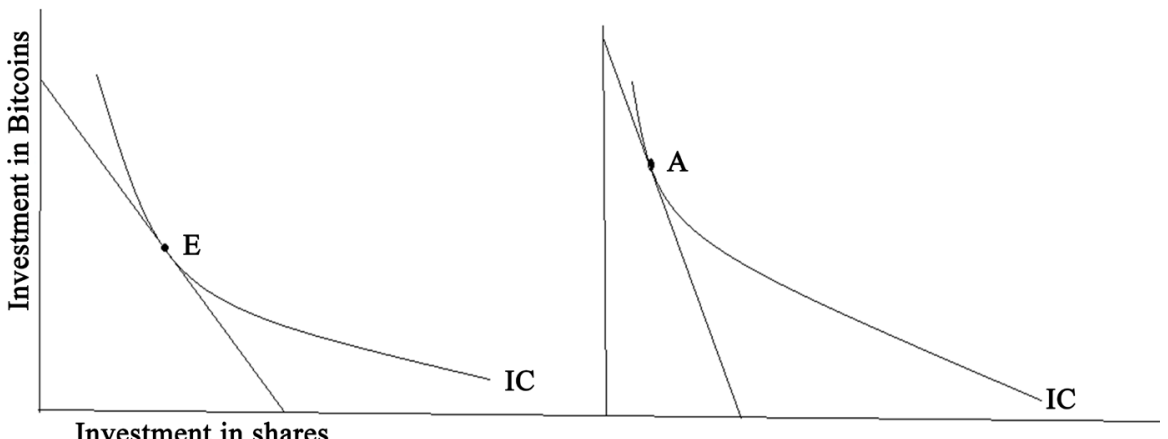

Figure 2. Choice-guided pre and post narrative formulation.

${ }^{1}$ Such a narrative positively influences the consumption of bundle A. 


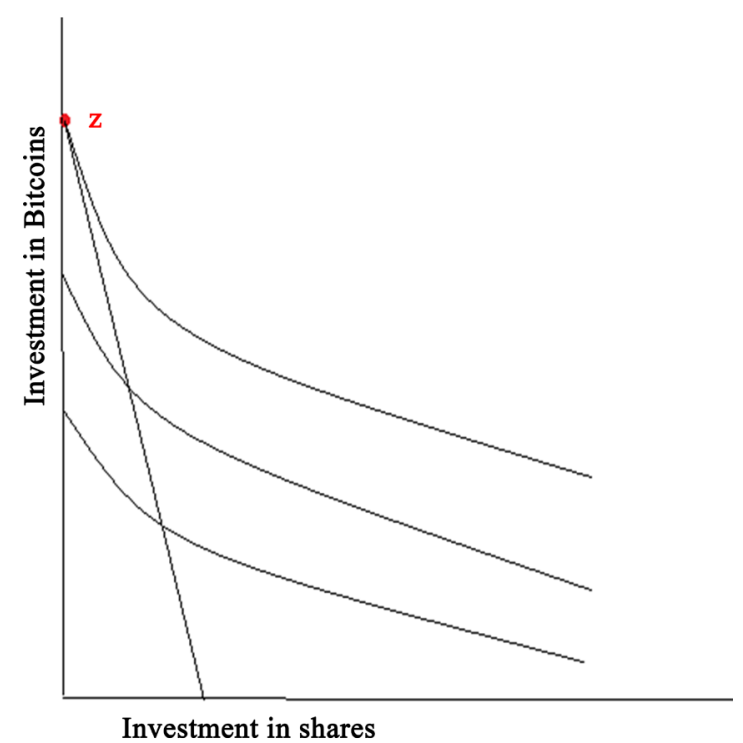

Figure 3. Narrative choice and corner solution.

Bitcoins than earlier. Further, if the choices are so skewed that the consumer is unwilling to buy the other good (shares in our case), the corner solution is reached where he ends up spending his entire income on one good. Such extreme choice skewed the consumption towards the good, which is targeted by narratives (Figure 3). Notably, the movement from $\mathrm{E}$ to $\mathrm{A}$ is driven by narrative. The consumer shall take complete information as imperative since information asymmetries can cause a skewed choice; further, the state shall apply to behavioral nudge to ensure individuals choose $\mathrm{E}$.

In Figure 3, the narrative prevalent in the economy influences consumer choices, and henceforth, the equilibrium is at the $\mathrm{Y}$-axis where only Bitcoins are bought, creating a skewed choice behavior. Also, the individuals showing favoritism to bitcoins can settle anything such that investments in Bitcoins, say $y_{1}$, are greater than Investments in shares, say $x_{1}$ such as $x_{1} \leq y_{1}$.

\subsection{Economic Efficiency: A Glimpse through Edge Worth Box}

In his seminal work of economic efficiency, Wilfred Pareto (1848-1923) postulated the "Pareto improvement", which objectively estimates efficiency as any change that makes at least one individual better-off, without making anyone else worse off, enhances social welfare.

An attempt here has been made to testify consumer choices and the shapes of the contract curve if the narrative influences the consumer choices. Figure 4 iterates consumers' choice towards good Y (bitcoins in the above case) since the narrative influences its choice. The contract curve hence bulges towards $\mathrm{Y}$-axis because both the individuals prefer more of $\mathrm{Y}$ and less of $\mathrm{X}$ due to the narrative that favors $\mathrm{Y}$.

Emphatically, if consumers' choices skew towards the particular good, resultantly, a producer shall follow the same suit and would produce more of the good in 


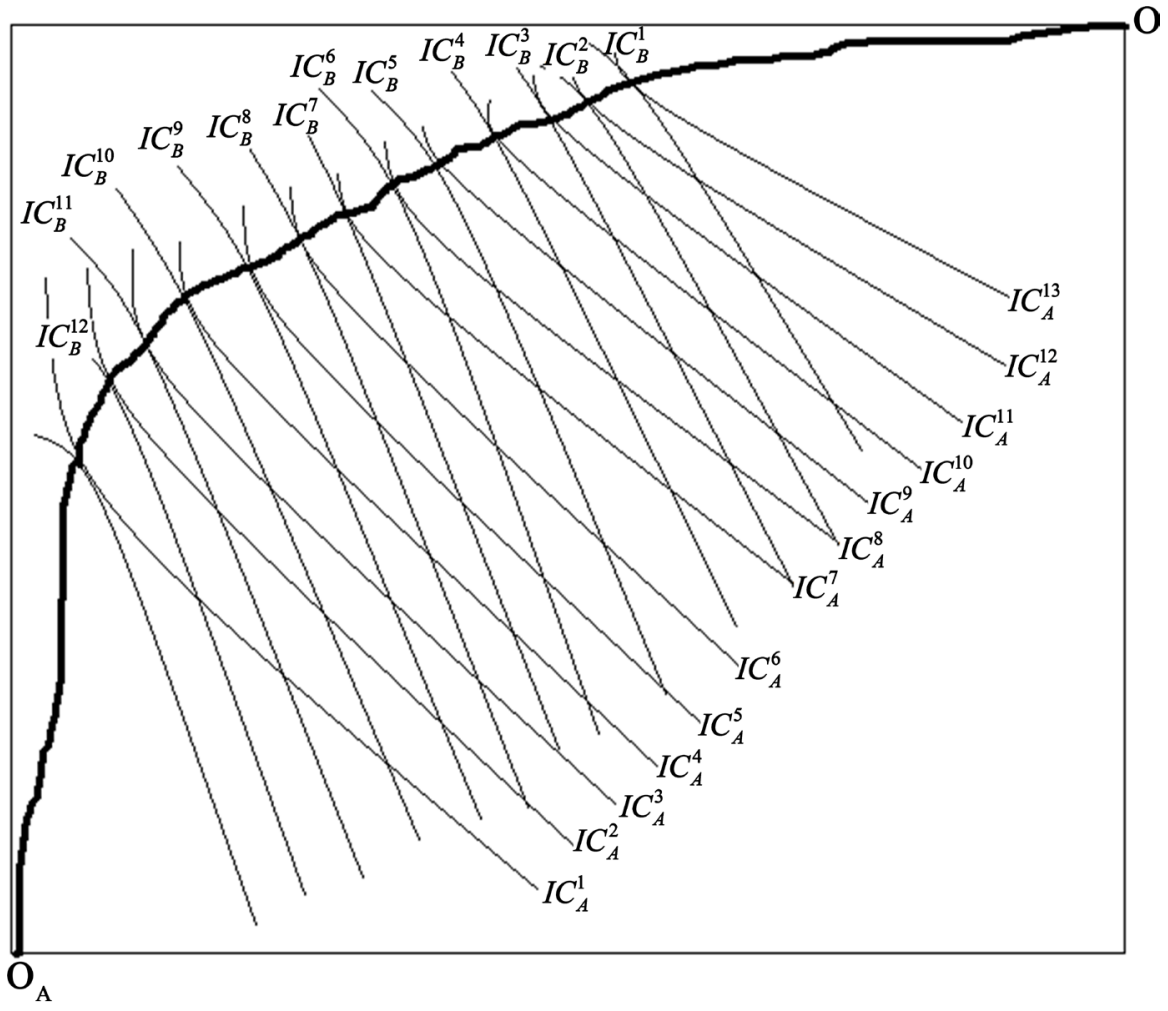

Figure 4. Edgeworth box for the narrative choice of consumers.

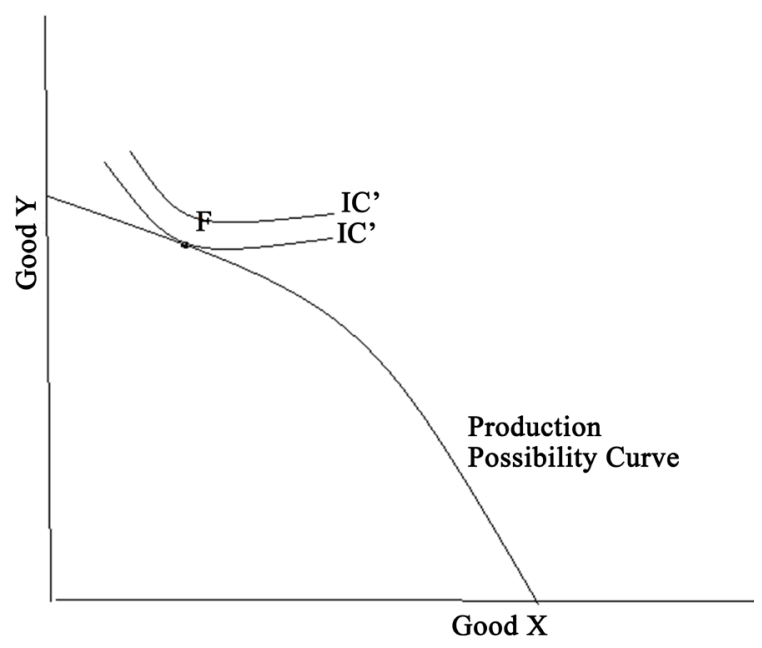

Figure 5. Allocation of resources; the case of narrative choices.

demand. The upshot of such behavior is a disproportionate allocation of resources towards the good under demand for which a favorable narrative exists. Figure 5 illustrates the case where narrative choices were favoring consumption and producing good $\mathrm{Y}$ lead to a higher allocation of resources.

\subsection{Theory of Revealed Preference: An Alternate in Case of Narrative choices}

Paul Samuelson postulated the theory of revealed preference, which states that: 
"If a consumer buys some bundle say, $A\left(x_{1}, x_{2}\right)$, rather than the other available $B, C \ldots D$ and all these bundles are less expensive or equally expensive than $\mathrm{A}$. Then it is said that A has been preferred over other bundles or other bundles are revealed inferior to $A$. ." (Samuelson, 1948)

If a consumer chooses bundle $A\left(x_{1}, x_{2}\right)$ over $B\left(y_{1}, y_{2}\right)$ with prices $\left(p_{1}, p_{2}\right)$ such that

$$
P_{1} x_{1}+p_{2} x_{2} \geq p_{1} y_{1}+p_{2} y_{2}
$$

Then A is revealed preferred over $B$.

SARP (Strong Axiom of Revealed preference): if $\left(x_{1}, x_{2}\right)$ is directly or indirectly revealed preferred to $\left(y_{1}, y_{2}\right)$, then $\left(y_{1}, y_{2}\right)$ cannot be revealed preferred to $\left(x_{1}, x_{2}\right)$, if $\left(x_{1}, x_{2}\right)$ and $\left(y_{1}, y_{2}\right)$ are different.

The theory of revealed preference can apply in the case where narrative guides choice patterns. It is important to note here that while revealed preference theory can apply to study consumer choices and decisions in the said scenario, its limitations prevail. Further, the implications of narrative choices, as explained above, cannot be ruled out in the form of skewed choices, production, and distribution.

Figure 6 illustrates that the consumer chooses bundle $\mathrm{Z}$ without existing narratives and reveals inferior the rest of the bundles, i.e., given the income, the consumer will always choose bundle $\mathrm{z}$ and not the other bundles lying on/below the budget line. Notably, post narrative formulation, which guides and favors the consumption of good $\mathrm{Y}$, the consumer reveals his preferences to be $\mathrm{Z}$ ' where he consumes more of $\mathrm{Y}$ and less of $\mathrm{X}$.

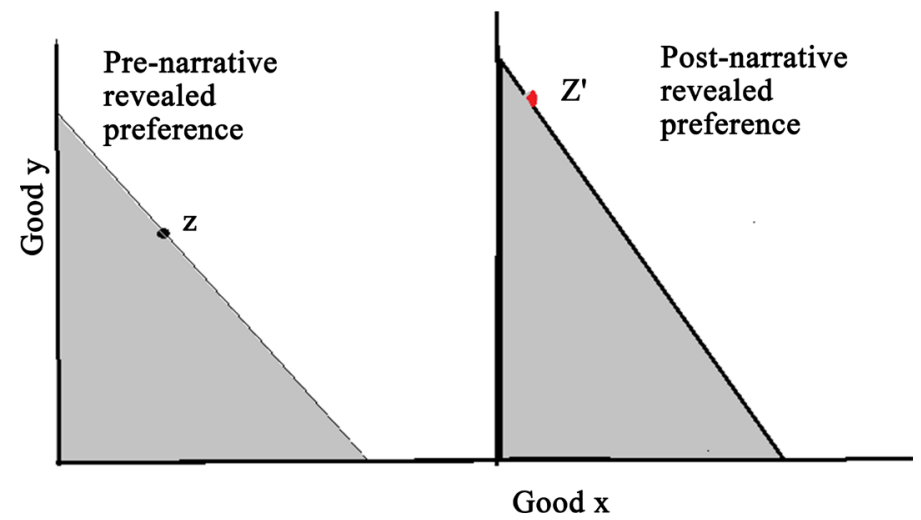

Figure 6. Revealed preferences, pre and post narrative.

Throughout the micro perspective, it has been observed how narrative can influence the individual(s) choices and decisions. The next segment of the study conceptualizes the macro view of narratives and their consequences on economic situation and inequality.

\section{Macro View on Narrative Economics}

From the contemporary works in economics, one can conceptualize the inter- 
connection between herd behavior with the stock market, the stock market with the financial sector, the financial sector with the service sector, and finally, the service sector to economic growth. There are many empirical shreds of evidence in economics, which focused on the relationship between the financial market and economic fluctuations. It is a well-recognized phenomenon that the country's overall financial and economic condition influences the money and capital fluctuations in the medium and long run. Goldsmith's (1969) work on analyzing the relationship between financial structure and economic development has been a pioneer in this domain. Further, the seminal works by King \& Levine (1993; 1994) work on the same lines, and most of them concluded that the growth in the financial markets in general and stock markets, in particular, significantly contribute to economic growth, through the provision of services such as liquidity, mobilization of resources, corporate governance, and amelioration of risks and informational symmetry.

Empirical findings of the financial market and its fluctuation have reflected that the financial market depends on the stock price fluctuations and the price of respective financial assets. Nevertheless, one cannot establish its impact on market fluctuations. The direction of correlation, i.e., whether they are correlated positively or adversely, is not known. The reality is that critical alterations in prices are not necessarily related to the arrival of information (Cutler, 1989) or variations in fundamental economic variables (Shiller, 1989). That instigates us to think that the high changeability existing in stock market returns may match collective phenomena such as "crowd effect" or "herd behavior".

Although herding in financial markets is by now relatively well documented both empirically and theoretically, there have been few studies on the implications of herding and imitation for the statistical properties of market demand and price fluctuations. In studying narrative economics, insufficient data, statistics availability, and lack of technological tools, it is impossible to empirically establish the correlation among crowd effects, herd behavior, and narratives with the developmental process.

\subsection{Narratives and Economic Fluctuations}

In this segment, the study synthesizes the relationship between purposeful narratives and economic fluctuations. The effect of both of these factors would be analyzed to observe the implications of economic growth and development. In the words of Shiller (2017), "By narrative economics I mean the study of the spread and dynamics of popular narratives, the stories, particularly those of human interest and emotion, and how these change through time, to understand economic fluctuations." There exist some literature which conceptualizes the relationship between narrative and economic fluctuation. The work of Robert Shiller on Narrative Economics (Shiller, 2017) is one of the landmarks in the domain of studying narrative economics. While in the sphere of narratives and environmental study, the work of Adger et al. (2001), Paulson \& Gezon (2005) 
and Brosius (2006) are prominent.

"Narrative Economics" is a field of study that tries to determine and analyze the implications on human species' choice and behavior in their economic and political activities such as income, consumption, saving, investment, and voting preferences. It also deals with how these economic activities are influenced by purposeful narratives coined by famous, wealthy, and powerful agents and institutions of the community.

The people's behavior can be visualized clearly in the period of the business cycle (expansion, crisis, recession, recovery) (Schumpeter, 1954), especially the people who deal with financial market trading. In the words of Shiller (2017), "A recession, for example, is a time when many people have decided to spend less, to make do for now with that old furniture instead of buying new, or to postpone starting a new business, to postpone hiring new help in an existing business, or to express support for fiscally conservative government." With the availability of present technology and data and statistical resources, it is quite complicated to investigate the empirical linkages between narratives and financial market changes. However, on the other side, the relationship cannot be ignored as well. However, one can establish the correlation theoretically, and this study tries to conceptualize the relationship described above. The existing literature on the said relationship includes Shiller (1984), which focuses on the importance of "social dynamics" and "popular models." Also, the work of on "culturnomics," McCloskey (2016), on "humanomics" and "narratives" in economics by Morson \& Shapiro (2017) has been a good source of learning in this emerging field.

The profound work of Robert Shiller in the dimension of Narratives Economics has created the way for Neo-modern ${ }^{2}$ Economics in which behavioral sciences correlate with developmental economics.

\subsection{Narratives and Economic Fluctuations: Depression, Recession, and Revival}

\subsubsection{Narratives and the Great Depression (1929-1930)}

The crash of the market-driven economy first time observed in 1929 in history. The demand and supply mechanism based on the theory of "invisible hand" by Adam Smith and the Says' Law, which states that "supply creates its own demand," collapsed at the beginning of the 1930s. Critically low economic activities such as production, consumption, and investment are implicated in high unemployment, galloping inflation, and widespread poverty. There has been extensive work on the causes and effects of the Great Depression. The work of John Maynard Keynes on the "Effective Demand" (Keynes, 1936) and the role of Government in the book "General Theory of Employment, Interest, and Money" in 1936, recognized as the great work in the history of modern economics. The

${ }^{2}$ Authors coined the term "Neo-Modern Economics" as a field of economic study that correlates behavioral sciences and developmental economics. 
idea of the mechanism of macroeconomics has been formulated with this work. Several economists have subsequentially developed empirically and conceptual works in the domain of macro and developmental economics.

The crash in the financial market due to the stock market drop was one of the prominent causes of the Great Depression. Robert Shiller explains the correlation between the intensity of narratives and the stock market crash in 1929. Robert Shiller noted that "the first narrative of the Great Depression was that of the stock market drop on October 28, 1929. This narrative was compelling, in its suddenness and severity, focusing public attention on a crash as never before in America".

\subsubsection{Narratives and Revival}

The policy analysts worldwide have immeasurably appreciated Keynes' work on the effective demand, consumption, and role in reviving the economy. The increase in the consumption level still plays an instrumental role in the increasing economic growth in the short-run and economic development in the medium and long run. In the year 1930, the Washington D.C. Chamber of Commerce launched a campaign with the slogan "Buy Now for Prosperity." A "Prosperity Committee" sought the participation of clergymen of all denominations to "preach prosperity through their pulpits" and thereby to "stimulate production, relieving the unemployment situation”. In 1932, Mrs. Charles E. Foster reportedly told a women's group: "One of the most effective weapons in the hands of American women today is their tremendous purchasing power. We are told that they spend eighty-five percent of the incomes of the United States. How could they better create public opinion in favor of spending as usual than by setting the example themselves?" These kinds of stories and punch lines have been used worldwide by popular agents to help the economy by influencing individual and community behavior. Figure 7 displays the intensity and frequency of terminology

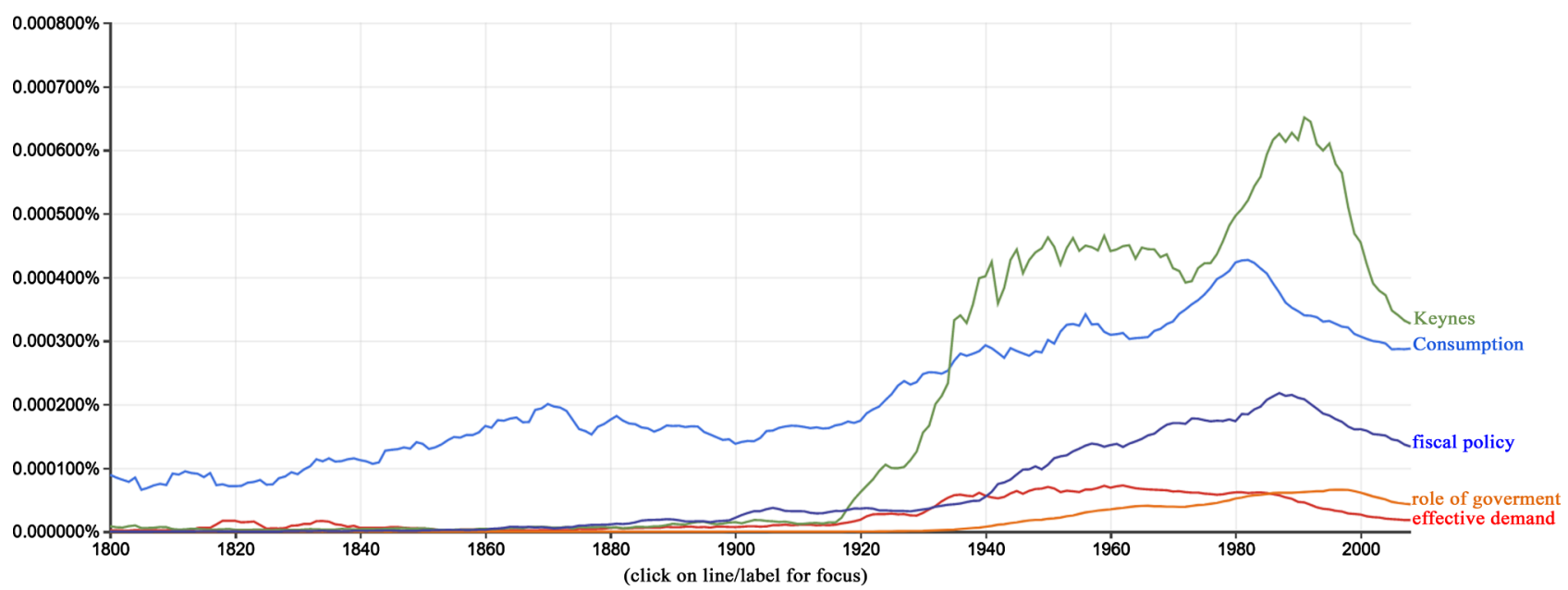

Source: Google Ngram.

Figure 7. The existence of narrative using Ngram. 
usages, such as Keynes's effective demand, consumption, government role, and fiscal policy.

Figure 7 envisages the usage of words, i.e., Keynes, Consumption, fiscal policy, the role of Government, and effective demand over more than two centuries since 1800. The "Keynesian Economics" gained momentum during early 1910; while the narrative was building, it gained momentum by the 1930s. Since then, this narrative strongly prevailed until 1960, although it faced few dents in the subsequent decade and gained momentum until 1990. The post-1990 period has experienced a fall in the usage of the terminologies mentioned above until 2008. The coherence in the shape of the Keynes curve, consumption curve, and fiscal policy curve reinstate simultaneous narratives across the last century (Figure 7).

\subsubsection{Narrative Economic Transition and Inequality}

Purposeful narratives generated by wealthy, powerful, and famous agents, institutions, or individuals can swiftly sweep economic agenda from developmental to overhauled political motives. Here the narratives are populist and are not necessarily bound to enhance economic development and welfare. Such non-developmental narratives then attract the resources of the State and hence lead to misallocation and concentration to few. Further, unfavorable outcomes can emerge due to the proliferation of non-developmental narratives. Figure 8 shows the changes in the level of development in the long run through narratives.

The undesired economic outcomes, such as increased unemployment, reduced economic growth, stagflation, and growing inequality, may follow from hailing non-developmental narratives for populist agendas.

Our study's foremost objective is to iterate the linkages between narratives deliberated by powerful agents and subsequent concentration of wealth. Figure 9 calibrates the said association. A few wealthy and resourceful people can swing the narrative and build upon by the low literacy, learning poverty, lack of rational

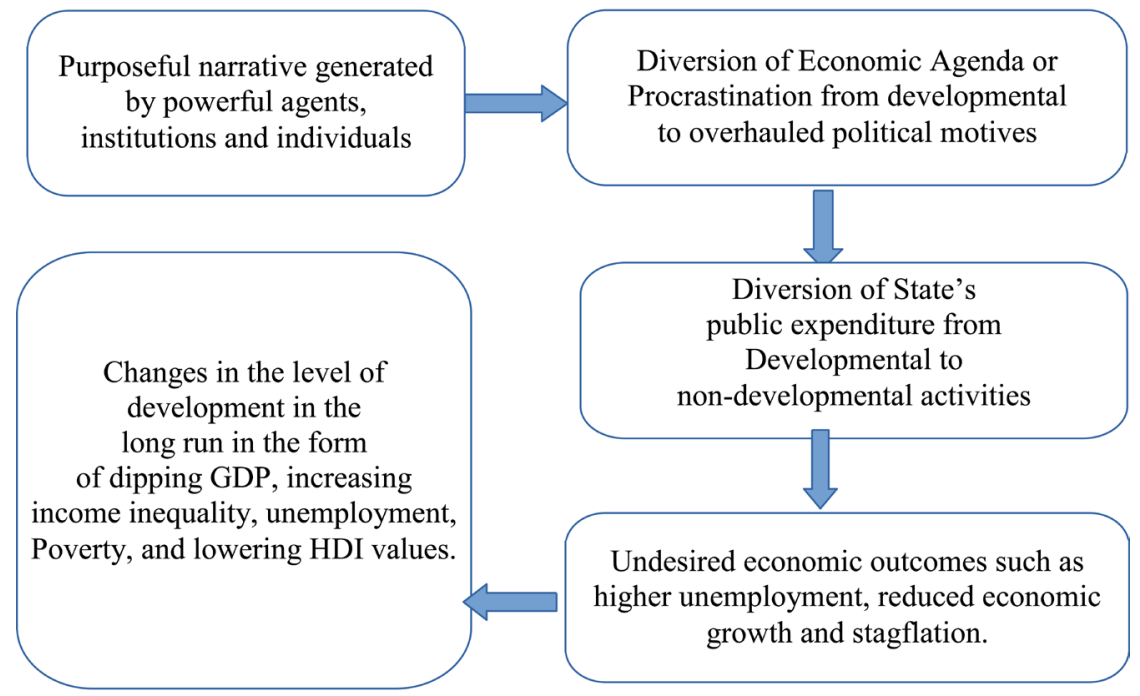

Figure 8. Narratives and economic slowdown. 


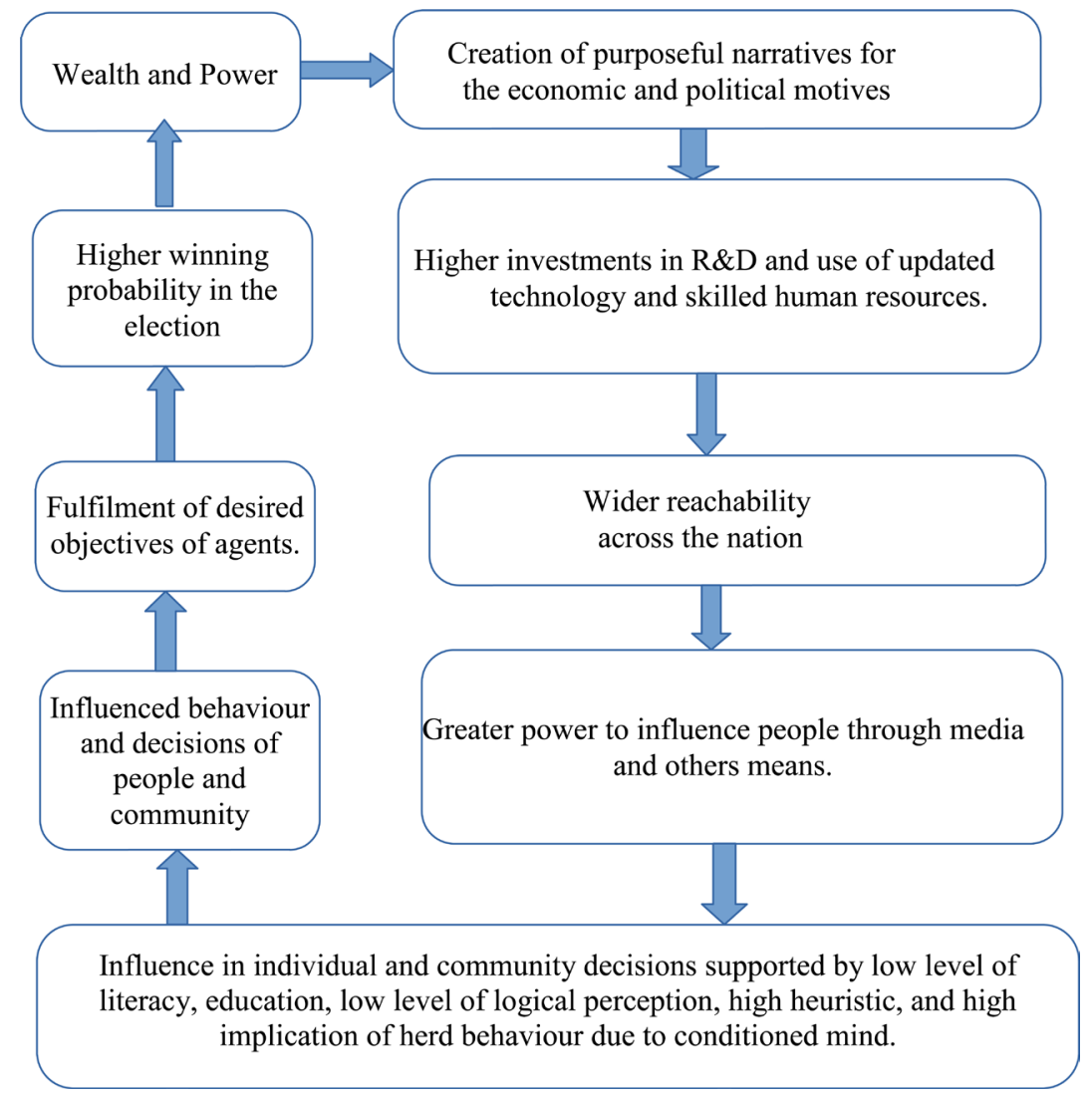

Figure 9. Linkages among wealth, power, narratives, media, and peoples' perception.

approach, religious and caste factors. Such narratives subsequently influence people's decisions, often their political decision, which enhances their probability of acquiring more wealth, leading to a perpetual concentration of wealth and power in few hands. The holding-up model, as explained by Banerjee \& Daflo (2003), states the efficiency loss while bargaining between the two political groups. Augmenting our argument of power concentration can ultimately erode the growth opportunity if the powerful group decides so. The studies of Bourguignon \& Verdier (2000) postulate an institutional setup in which the wealthy elite will suppress democracy and equal rights before law to secure his position. Acemoglu et al. (2001) also models the blockade created by the oligarchy in democracy to secure its privileges; also, Bourguignon \& Verdier (2000) wested that niche will suppress democracy and equal rights before the law in order to cement their position. Rajan \& Zingales (2006) presented that the niche and the educated middle class will form a syndicate against education for the poor to bypass largescale reform and subsequent abrasion of the rents manifesting to the already educated. While studying the human capital mechanism (Galor \& Zeira, 1993; Perotti, 1996; Galor \& Moav, 2006; Galor et al., 2006) observes that imperfect capital markets shall hinder human capital accumulation with the poor majority. The present study not just reiterates the concentration of wealth by precious elites but also "perpetual concentration" due to the formulation and smooth 
proliferation of narratives by them, which cements the process of concentration of power and wealth by the enhanced likelihood of acceptance among the poor masses. Such inequality hence created, will lead to nothing less than social chaos, will dampen growth, and increase trade deficit Chowdhary \& Dasgupta (2015). Here few people acquire the power to build and proliferate narratives and reassert

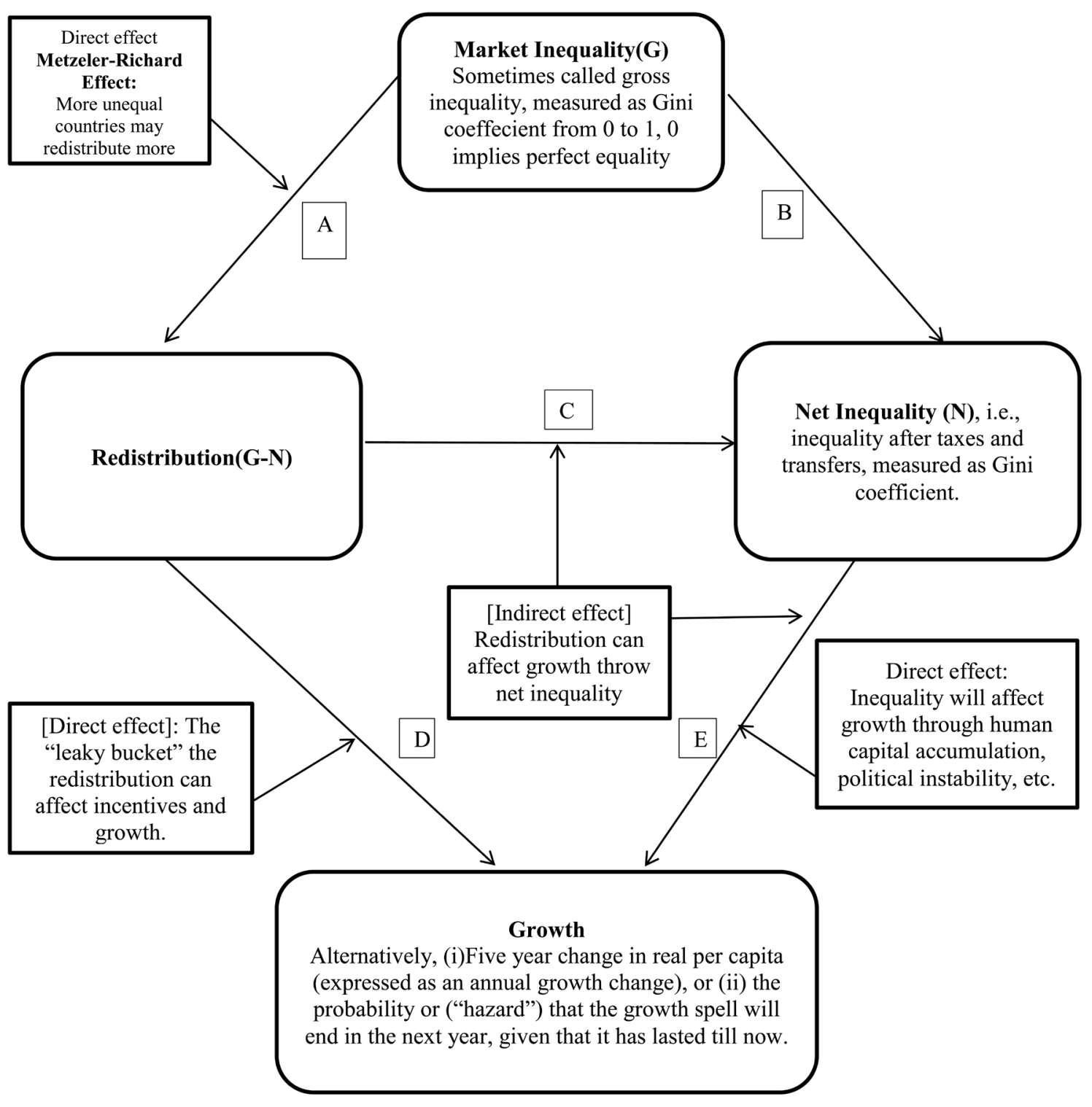

Note: This picture shows the main channels of influence investigated in this paper. We estimate econometrically the direct fects of redistribution(line D) And Net inequality(line E), in each case in effect holding the value of the other variable constant. We also calculate the "total effect" of redistribution on growth. We assume that redistribution does not affect market inequality, so redistribution affects net inequality one-for-one. The total effect is thus the sum of the estimated direct effect(line D) and the indirect effect, which is a combination of the effect of redistribution on net inequality(line $\mathrm{C}$ ) and the estimated direct effect of net inequality on growth (line E). There are many other arrows one could draw in the picture, such as from growth back to inequality and redistribution. In addition, there are possible channels that relate the levels of income, inequality, and redistribution. The paper emphasized those shown here, as discussed in the text. Source: (Ostry et al., 2014). Necessary research (Benabou, 2000, 2002; Bleaney, Gemmell, \& Kneller, 2001) ooze out that specific classification of government expenditure-i.e., public investments in infrastructure, spending on health and education, and social insurance provision-perhaps are both pro-growth and pro-equality.

Figure 10. Interrelationships between inequality, growth, and redistribution. 
their position, power, and wealth once successful. The significant findings relate to the fact that there is a strong causal relationship between inequality and narrative, reinforcing each other. The reason for the "perpetual concentration" of wealth and power lies with the existence of strong narratives that directly or indirectly reinforces aggrandizement and cause penury to the few left out underprivileged sections. Such inequality will be nothing short of being narrative-driven inequality.

However, such inequality pulls government expenditure and redistribution policies (Figure 10). Ostry et al. (2014) deduced a robust positive impact of inequality on redistribution, i.e., higher inequality exacerbates redistribution.

\section{Epilogue}

The resources skew towards the goods whose preference is influenced by existing narratives. On a macro level, such narratives have a far-reaching impact since the information can swing significant buying behaviors, production, and income distribution. Narratives generally favor one stratum of society, the upshot of which it allocates resources disproportionately to them. Make the weaker section perpetually weaker by keeping the fruits of development at bay from them. Such inequalities can jeopardize the growth process, can augment social chaos and trade deficit. The present study is intrigued by the fact that narratives form an inextricable role while implementing state policies; moreover, non-developmental narratives can dampen the impact of desired policy and economic objectives and vice-a-versa. Importantly, since facts do not always back narratives, unpredictable economic and social outcomes petered out from conventional policy action.

From the policy formulation perspective, it is essential to note that the policies are formed while keeping in mind rational and unbiased buying behavior. Such prejudice not only leads to wrong policy formulation but the policy paralysis. However, an abrupt narrative can lead to a policy collapse and misallocation of resources. Policymakers must keep in mind the prevalent or potential narratives of the economy. The State shall adopt fiscal policies of progressive taxation and rigorous dissemination to ensure an egalitarian society.

Moreover, the role of the ministry of information and technology is imperative, and it should act with autonomy against false narratives deliberately build by the powerful parties. The role of autonomous institutions such as the judiciary is prominent while curtailing such sources of concentration of power.

The research can be further extended to understand narratives from a deeper perspective, i.e., in the domain of luxury goods and inferior goods.

\section{Conflicts of Interest}

The authors declare no conflicts of interest regarding the publication of this paper.

The perpetual concentration of wealth: concentration of wealth followed by subsequent accumulation facilitated by the narrative. (Authors' definition). 


\section{References}

Abbott, H. P. (2002). The Cambridge Introduction to Narrative (p. 16). Cambridge: Cambridge University Press.

Acemoglu, D. et al. (2001). The Colonial Origins of Comparative Development. American Economic Review, 91, 1369-1401. https://doi.org/10.1257/aer.91.5.1369

Adger, W. N., Benjaminsen, T. A., Brown, K., \& Svarstad, H. (2001). Advancing a Political Ecology of Global Environmental Discourses. Development and Change, 32, 681-715. https://doi.org/10.1111/1467-7660.00222

Akerlof, G. A., \& Shiller, R. J. (2009). Animal Spirits: How Human Psychology Drives the Economy and Why This Matters for Global Capitalism. Princeton, NJ: Princeton University Press.

Akerlof, G. A., \& Shiller, R. J. (2015). Phishing for Phools: The Economics of Manipulation and Deception. Princeton, NJ: Princeton University Press. https://doi.org/10.2307/j.ctvc777w8

Allen, C. J., \& Hockey, J. (2008). Autoethnography as Valid Methodology? A Study of Disrupted Narratives. The International Journal of Interdisciplinary Social Sciences, 3, 209-217. https://doi.org/10.18848/1833-1882/CGP/v03i06/52631

Allison, S. T., Jordan, A. M. R., \& Yeatts, C. E. (1992). A Cluster-Analytic Approach toward Identifying the Structure and Content of Human Decision Making. Human Relations, 45, 49-72. https://doi.org/10.1177/001872679204500103

Banerjee, A. V., \& Duflo, E. (2003). Inequality and Growth: What Can the Data Say? Journal of Economic Growth, 8, 267-299. https://doi.org/10.1023/A:1026205114860

Beckar, G. S. (1974). A Theory of Social Interactions. Journal of Political Economy, 82, 1063-1093. https://doi.org/10.1086/260265

Benabou, R. (2000). Unequal Societies: Income Distribution and the Social Contract. American Economic Review, 90, 96-129. https://doi.org/10.1257/aer.90.1.96

Benabou, R. (2002). Tax and Education Policy in a Heterogeneous-Agent Economy: What Levels of Redistribution Maximize Growth and Efficiency? Econometrica, 70, 481-517. https://doi.org/10.1111/1468-0262.00293

Benabou, R., \& Tirole, J. (2006). Incentives and Prosocial Behavior. American Economic Review, 96, 1652-1678. https://doi.org/10.1257/aer.96.5.1652

Bleaney, M., Gemmell, N., \& Kneller, R. (2001). Testing the Endogenous Growth Model: Public Expenditure, Taxation, and Growth over the Long Run. Canadian Journal of Economics, 34, 36-57. https://doi.org/10.1111/0008-4085.00061

Bolton, G. E., \& Ockenfels, A. (2000). ERC: A Theory of Equity, Reciprocity, and Competition. The American Economic Review, 90, 166-193.

https://doi.org/10.1257/aer.90.1.166

Bourguignon, F., \& Verdier, T. (2000). Oligarchy, Democracy, Inequality and Growth. Journal of Development Studies, 62, 285-313. https://doi.org/10.1016/S0304-3878(00)00086-9

Brosius, J. P. (2006). Common Ground between Anthropology and Conservation Biology. Conservation Biology, 20, 683-685. https://doi.org/10.1111/j.1523-1739.2006.00463.x

Brown, J., Abdallah, S. S., \& Ng, R. (2011). Decision Making Styles East and West: Is It Time to Move beyond Cross-Cultural Research. International Journal of Sociology and Anthropology, 3, 452-459.

Can, H. (1991). Organizasyon ve Yönetim. Adım Yayıncılık, Ankara. 
Chowdhary, S., \& Dasgupta, Z. (2015). Growth, Imports and Inequality. Economic and Political Weekly, 50, 65.

Cutler, D. (1989). What Moves Stock Prices. Journal of Portfolio Management, 15, 4-12. https://doi.org/10.3905/jpm.1989.409212

Escalas, J. E. (2007). Self-Referencing and Persuasion: Narrative Transportation versus Analytical Elaboration. Journal of Consumer Research, 16, 421-429. https://doi.org/10.1086/510216

Falk, A., \& Tirole, J. (2016). In Face of Yourself-A Note on Self-Image. Mimeo.

Fehr, E., \& Schmidt, K. M. (1999). A Theory of Fairness, Competition, and Cooperation. The Quarterly Journal of Economics, 114, 817-868. https://doi.org/10.1162/003355399556151

Glaeser, E. L. (2005). The Political Economy of Hatred. Quarterly Journal of Economics, 120, 45-86. https://doi.org/10.1162/0033553053327434

Galor, E., \& Moav, O. (2006). Das Human Kapital: A Theory of the Demise of the Class Structure. Review of Economic Studies, 73, 85-117. https://doi.org/10.1111/j.1467-937X.2006.00370.x

Galor, E., Moav, O., \& Vollrath, D. (2006). Land Inequality and the Emergence of Human Capital Promoting Institutions. Brown University Working Paper. https://doi.org/10.2139/ssrn.670883

Galor, O., \& Zeira, J. (1993). Income Distribution and Macroeconomics. Review of Economic Studies, 60, 35-52. https://doi.org/10.2307/2297811

Gino, F., Norton, M. I., \& Weber, R. A. (2016). Motivated Bayesians: Feeling Moral While Acting Egoistically. Journal of Economic Perspectives, 30, 189-212. https://doi.org/10.1257/jep.30.3.189

Goldsmith, R. W. (1969). Financial Structure and Development. New Haven, CT: Yale University Press.

Hicks, J., \& Allen, R. (1934). A Reconsideration of the Theory of Value. Part I. Economica, 1, 52-76. https://doi.org/10.2307/2548574

Kahneman, D. (2011). Thinking: Fast and Slow. London: Allen Lane.

Kaltsounis, T. (1987). Teaching Social Studies in the Elementary School. Upper Saddle River, NJ: Prentice Hall.

Kay, J. (2012). The Kay Review of UK Equity Markets and Long-Term Decision Making. HM Government.

https://assets.publishing.service.gov.uk/government/uploads/system/uploads/attachme nt data/file/253454/bis-12-917-kay-review-of-equity-markets-final-report.pdf

Keynes, J. M. (1936). The General Theory of Employment Interest and Money. London: Palgrave Macmillan.

King, R. G., \& Levine, R. (1993). Financial Intermediation and Economic Development. In C. Mayer, \& X. Vives (Eds.), Financial Intermediation in the Construction of Europe (pp. 156-189). London: Centre for Economic Policy Research. https://doi.org/10.1017/CBO9780511752056.011

King, R. G., \& Levine, R. (1994). Capital Fundamentalism, Economic Development and Economic Growth. Carnegie-Rochester Conference Series on Public Policy, 40, 259-292. https://doi.org/10.1016/0167-2231(94)90011-6

Lazonick, W. (2014). Profits without Prosperity. Harvard Business Review, September 2014. https://hbr.org/2014/09/profits-without-prosperity 
Leibenstein, H. (1950). Bandwagon, Snob, and Veblen Effects in the Theory of Consumers' Demand. The Quarterly Journal of Economics, 64, 183-207. https://doi.org/10.2307/1882692

Machill, M., Sebastian, K., \& Markus, W. (2007). The Use of Narrative Structures in Television News. European Journal of Communication, 22, 185-205. https://doi.org/10.1177/0267323107076769

McCloskey, D. (2016). Adam Smith Did Humanomics: So Should We. Eastern Economic Journal, 42, 503-513. https://doi.org/10.1057/s41302-016-0007-8

McGregor, J. A., \& Pouw, N. (2017). Towards an Economics of Wellbeing: What Would Economics Look like If It Were Focused on Human Wellbeing? Cambridge Journal of Economics, 41, 1123-1142.

McQuiggan, S. W., Jonathan, P. R., Sunyoung, L., \& James, C. L. (2008). Story-Based Learning: The Impact of Narrative on Learning Experiences and Outcomes. In B. P. Woolf, E. Aïmeur, R. Nkambou, \& S. Lajoie (Eds.), Intelligent Tutoring Systems (pp. 530-539). Berlin: Springer. https://doi.org/10.1007/978-3-540-69132-7 56

Mishan, E. (1961). Welfare Criteria for External Effects. The American Economic Review, 51, 594-613. http://www.jstor.org/stable/1812787

Morson, G. S., \& Schapiro, M. (2017). Cents and Sensibility: What Economics Can Learn from the Humanities. Princeton NJ: Princeton University Press. https://doi.org/10.1515/9781400884841

Nesvetailova, A. (2019). Shadow Banking: Scope, Origins and Theories. London: Routledge.

Ostry, J., Berg, A., \& Tsangarides, C. (2014). Redistribution, Inequality, and Growth. Staff Discussion Notes, No. 14, 1. https://doi.org/10.5089/9781484352076.006

Paulson, S., \& Gezon, L. (2005). Political Ecology across Spaces, Scales, and Social Groups. New Brunswick, NJ: Rutgers University Press.

Perotti, R. (1996). Growth, Income Distribution, and Democracy: What the Data Say. Journal of Economic Growth, 1, 149-188. https://doi.org/10.1007/BF00138861

Rabin, M. (1993). Incorporating Fairness into Game Theory and Economics. The American Economic Review, 83, 1281-1302.

Rajan, R., \& Zingales, L. (2006). The Persistence of Underdevelopment: Institutions, Human Capital, or Constituencies? NBER Working Paper No. 12093 Issued in March 2006. https://doi.org/10.2139/ssrn.977151

Sağır, C. (2006). Karar Verme Sürecini Etkileyen Faktörler ve Karar Verme Sürecinde Etiğin Önemi: Uygulamalı Bir Araştırma. Unpublished Master Dissertation, Edirne: Trakya University.

Samuelson, P. A. (1947). Foundations of Economic Analysis. Cambridge, MA: Harvard University Press.

Samuelson, P. A. (1948). Consumption Theory in Terms of Revealed Preference. Economica, 15, 243-253. https://doi.org/10.2307/2549561

Schumpeter, J. A. (1954). History of Economic Analysis. London: George Allen \& Unwin.

Shiller, R. J. (1984). Stock Prices and Social Dynamics. Brookings Papers on Economic Activity, New Haven, CT: Yale University. https://doi.org/10.2307/2534436

Shiller, R. J. (1989). Market Volatility. Cambridge, MA: MIT Press.

Shiller, R. J. (2016). Crash Beliefs from Investor Survey. NBER Working Papers 22143, Cambridge: National Bureau of Economic Research.

Shiller, R. J. (2017). Narrative Economics. Cowles Foundation Discussion Paper No. 2069, New Haven, CT: Yale University. https://doi.org/10.3386/w23075 
Shiller, R. J. (2019). Narrative Economics: How Stories Go Viral and Drive Major Economic Events. Princeton, NJ: Princeton University Press.

https://doi.org/10.1515/9780691189970

Simon, H. A. (1955). A Behavioral Model of Rational Choice. The Quarterly Journal of Economics, 69, 99-118. https://doi.org/10.2307/1884852

Slater, M. D., Buller, D. B., Waters, E., Archibeque, M., \& LeBlanc, M. (2003). A Test of Conversational and Testimonial Messages versus Didactic Presentations of Nutrition Information. Journal of Nutrition Education Behavior, 35, 255-259.

https://doi.org/10.1016/S1499-4046(06)60056-0

Snower, D. J., \& Akerlof, G. A. (2016). Bread and Bullet. Discussion Paper No. DP11132. https://papers.ssrn.com/sol3/papers.cfm?abstract $\mathrm{id}=2766423 \# \#$

Thaler, R. (2015). Misbehaving: How Economics Became Behavioral. London: Allen Lane.

Weber, K., Martin, M. M., Members of COMM 401, \& Corrigan, M. (2006). Creating Persuasive Messages Advocating Organ Donation. Communication Quarterly, 54, 67-87. https://doi.org/10.1080/01463370500270413 